\section{Birlesik Dünya Arastrirma Cypriot Journal of Educational BD-CENTER \\ Sciences}

Innovasyon ve Yayınalık Merkezi
Volume 15, Issue 3, (2020) 399-411

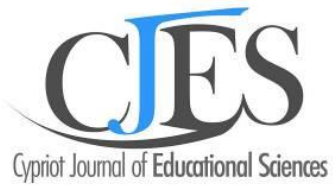

www.cjes.eu

\title{
Speaking Self-Efficacy Beliefs of Turkish University Students
}

\author{
Mehmet Volkan Demirel ${ }^{\text {a* }}$, Faculty of Education, Yozgat Bozok University, Yozgat 66900, Turkey, \\ https://orcid.org/0000-0001-7803-3310
}

Ali Türkel ${ }^{b}$, Buca Education Faculty, Dokuz Eylül University, İzmir 35100, Turkey. https://orcid.org/0000-0003-47438766

İbrahim Seçkin Aydın c, Buca Education Faculty, Dokuz Eylül University, İzmir 35100, Turkey. https://orcid.org/0000-0003-0610-863X

\section{Suggested Citation:}

Demirel, M. V., Türkel, A. \& Aydın, I. S., (2020). Speaking Self-Efficacy Beliefs of Turkish University Students. Cypriot Journal of Educational Science. 15(3), 399-411. DOI: 10.18844/cjes.v\%vi\%i.4905

Received from October 13, 2019; revised from February 15,2020; accepted from June 27, 2020.

${ }^{\circ} 2020$ Birlesik Dunya Yenilik Arastirma ve Yayincilik Merkezi. All rights reserved.

\begin{abstract}
Expressing thoughts and feelings effectively is a vital skill for individuals' professional career. University students should thus attach due importance to their communication skills as they receive their professional training. Self-efficacy beliefs can be regarded as an influential element in speaking skills, and may affect different aspects of speaking performance. In this respect, the aim of this study was to examine the speaking self-efficacy beliefs of final-year university students based on different variables. The reason why this study focused on final-year students was to determine the level at which they perceived themselves in terms of speaking in the pre-service period. Accordingly, the "Speaking Self-Efficacy Scale" was administered to 843 final-year students (454 female, and 389 male) studying at a Turkish university, and the data gathered were analysed through statistical methods. The results showed that the students' speaking self-efficacy levels were considerably high based on their scores on the scale. There was no significant difference between the students' self-efficacy beliefs based on gender, but they were observed to differ in their speaking self-efficacy beliefs based on their faculties. The analysis regarding the variable of experience in prepared speeches also revealed a significant difference in the students' speaking self-efficacy beliefs. Moreover, the university students' speaking self-efficacy beliefs were found to differ based on their annual amount of reading. It can be argued that improving the current level is possible through participation in more prepared speech activities and gaining a reading habit.
\end{abstract}

Keywords: Self - Efficacy beliefs, Speaking, Speaking skills.

\footnotetext{
* ADDRESS FOR CORRESPONDENCE: Mehmet Volkan Demirel, Faculty of Education, Yozgat Bozok University, Yozgat 66900, Turkey, E-mail address: m.volkan.demirel@yobu.edu.tr / Tel.: +903542427704
} 
Demirel, M., V., Türkel, A. \& Aydın, I., S., (2020). Speaking Self-Efficacy Beliefs of Turkish University Students. Cypriot Journal of Educational Science. 15(3), 399-411. DOI: 10.18844/cjes.v\%vi\%i.4905

\section{Introduction}

Verbal communication is needed in every part of daily life, and has great importance for vocational education and practising a profession. The ability to express thoughts and feelings effectively is one of the elements that should be taken into consideration for career planning. In this sense, university students should attach due importance to their communication skills as they receive their professional training. The significance of speaking skills that enable the verbal communication of feelings and thoughts have been highlighted by many researchers in the context of success in a variety of areas including work, personal life and social relationships (e.g. İşcan, 2013; İşcan \& Karagöz, 2016; İ̧can, Karagöz \& Almalı, 2017; Aydın \& Başoğlu, 2014; Uzuner Yurt \& Aktaş, 2016; Kuru, 2018). Şahan (2012) argues that the development of speaking skills should start during the first years of elementary education since individuals strive to improve their poor communicative performance even after they complete their higher education.

Physiological, psychological and social properties of speaking should be taken into account to achieve the objectives for developing speaking skills. Students' willingness to speak, beliefs about their own speech and worries regarding the communicative process should also be considered in addition to the models explaining other aspects of speaking skills. In other words, the development of verbal skills are directly related to psychology, social psychology, and behavioural and communicative sciences (Ünalan, 2007). In particular, the self-confidence of a successful speaker (Kuru, 2018) is considered as the main factor affecting a good speech in many ways. Likewise, Aydın (2013: 34) states that speaking involves many qualities unique to human beings starting with sounds, and individuals' speaking skills are also related to their beliefs. Self-efficacy beliefs can thus be regarded as an influential element in speaking skills.

Self-efficacy beliefs are defined as individuals' judgements of their abilities in organising and conducting actions necessary to achieve a certain level of performance in an area (Bandura, 1986:94). According to Bandura (1982:122), the higher individuals' stimulated self-efficacy level is, the higher their performance accomplishments are and the lower their emotional stimulation is. Furthermore, self-efficacy beliefs contribute to students' academic development by determining their beliefs and motivational levels regarding activities of regulation their learning and managing academic efforts, and achievement (Bandura, 1993:117).

In the literature, self-efficacy is assumed to affect task selection, effort, persistence and success (Bandura, 1986; Schunk, 1995). According to Schunk (2003:161), students who are self-efficacious attend activities more easily, put more effort in tasks, and show more persistence in the face of difficulties, when compared to the ones who doubt their abilities. Self-efficacy beliefs that form the basis for motivation, well-being and achievement (Pajares, Johnson \& Usher, 2007: 105) are shaped by individuals' interpretation of information from these four sources: mastery experience, vicarious experience, social persuasion, and physiological states such as anxiety and stress (Pajares, 2003).

As Adams (2004) states, the results of research studies show that speaking skills are a challenging issue for both undergraduate and graduate students, and they lack self-confidence for oral academic presentations. Ferris (1998) who examined students' needs of auditory verbal skills and their struggles in this area reported that they had difficulty in oral presentations and class discussions.

Dwyer and Fus (1999) investigated the relationship between self-efficacy for speaking in front of a crowd and communicative attitudes. They compared communicative attitudes, self-efficacy and achievement scores, and found that communicative attitudes and self-efficacy were reversely related, while self-efficacy significantly predicted achievement scores. In another study, Dwyer and Fus (2002) focused on the relationship between communicative skills, self-efficacy for speaking in front of a crowd and achievement scores. Likewise, they reported that self-efficacy predicted student achievement.

Warren (2011) investigated whether service learning had a role in students' self-efficacy for speaking in front of a crowd. The results revealed a weak correlation between self-efficacy for and the skill of speaking in front of a crown in general. Asakereh and Dehghannezhad (2015) who examined the relationship between speaking course satisfaction, speaking self-efficacy beliefs and speaking skills found that both 
satisfaction and self-efficacy were positively related to speaking skills. Aiming to identify efficacy levels for speaking skills, Katrancı and Melanlıoğlu (2013) emphasised the necessity of enhancing speaking selfefficacy beliefs. Paradewari (2017) examined the self-efficacy beliefs of English teacher candidates for speaking in front of a crowd. The candidates were found to have high self-efficacy in all sub-factors affecting self-efficacy that are mastery experience, vicarious experience, social persuasion, and physiological states such as anxiety and stress.

In recent years, there has been an increase in the number of studies conducted to investigate individuals' self-efficacy beliefs. Speaking self-efficacy beliefs is among these topics addressed in the literature. Courses that can enhance university students' self-efficacy beliefs towards oral communication (Schuurman et al., 2018; Frisby et al., 2020) or pedagogical practices that support their motivation are expected to have a direct impact on individuals' career (Mehta, 2018). Accordingly, it is of great significance to develop the communication skills of university students who are also pre-service teachers against the problems they may face in their professional lives, while equipping them with the knowledge and skills necessary for their future profession.

In this respect, the aim of this study was to examine the speaking self-efficacy beliefs of final-year Turkish university students based on different variables. The reason why this study focused on final-year students was to determine the level at which they perceived themselves in terms of speaking in the preservice period. The following research questions were answered in the study:

Do Turkish university students' levels of speaking self-efficacy beliefs differ based on:

a. gender?

b. faculty of study?

c. the number of prepared speech they have given before?

d. average number of books they read annually?

\section{Method}

This study was conducted in accordance with the case study design. The participants were 843 students (454 female and 389 male) studying their final year in the faculties of education, fine arts, letters, maritime, engineering, law, economics and administrative sciences, and theology, at İmir Dokuz Eylül University, Turkey. In the study, the "Speaking Self-Efficacy Scale" (Aydın, 2013) was used as the data collection instrument. The gathered data were analysed using statistical methods.

Speaking Self-Efficacy Scale (SSES): The SSES consists of four sub-dimensions that are "Planning the Speech (20 items)", "Speech Process (12 items)", "Linguistic Structure ( 9 items)" and "Audience Factor (5 items)". According to the results of the explanatory factor analysis, these four sub-dimensions explained $48.5 \%$ of the total variance. Confirmatory factor analysis (CFA) was conducted on the items obtained through the explanatory factor analysis. The factor loadings of the items ranged between .32 and .71. The alpha reliability coefficient was .94 for the first sub-dimension, .87 for the second, .89 for the third and .74 for the fourth. The coefficient for the whole scale was .95.

The missing values, outliers and the assumption regarding the suitability of the sample size were examined before starting the analyses. An average value was assigned to the missing values in the data set, whereas there were no outliers. The normality of the distribution of scores were examined to select the technique that would be used to determine the difference between the students' scores from the SSES, and the results are presented in Table 1.

Table 1. Results of the test of normality

SSES Total Score

Kolmogorov- Smirnov

$\begin{array}{ccc}K S & S D & p \\ .024 & 843 & .200\end{array}$

$\mathrm{N}=843 ; p>.05$ 
As is seen in Table 1, the students' scores showed normal distribution, and accordingly, parametric tests were used to determine the difference. In this regard, t-test, a non-parametric test, was used to see whether there was a difference between the participants' scores based on gender, and ANOVA, a parametric test, was employed for any significant differences based on number of previous prepared speeches and amount of annual reading.

The normality of the distribution of scores were also examined to select the technique that would be used to determine the difference between the students' scores from the sub-scales of the SSES (i.e. planning, drafting, and revision and modification), and the results are presented in Table 2.

Table 2. Results of the Test of Normality for the Sub-Dimensions of SSES

\begin{tabular}{cccc}
\hline & \multicolumn{3}{c}{ Kolmogorov-Smirnov } \\
\hline & $K S$ & $S D$ & $p$ \\
Planning the speech & .036 & 843 & .011 \\
Speech process & .049 & 843 & .000 \\
Linguistic structure & .076 & 843 & .000 \\
Audience factor & .105 & 843 & .000 \\
\hline
\end{tabular}

As is seen in Table 2, the scores in the sub-dimensions did not show a normal distribution $(p<.05)$. Mann Whitney $U$, a non-parametric test, was used to see whether there was a difference between the participants' scores in the sub-dimensions of the SSES based on gender, and Kruskal Wallis Test, also a non-parametric test, was employed for any significant differences based on faculties, number of previous prepared speeches and amount of annual reading.

The arithmetic mean intervals set by Tekin (1996) were used in the interpretation of the students' scores in the whole scale and its sub-dimensions. These intervals were "1.00 - 1.80=Very low", "1.81 - 2.60= Somewhat low", "2.61 - 3.40= Moderate", "3.41 - 4.20= High", "4.21 - 5.00= Very High".

\section{Results}

The results of the analysis on the university students' self-efficacy beliefs are presented in Table 3 with regard to the whole scale and its sub-dimensions.

Table 3. University Students' Levels of Speaking Self-Efficacy

\begin{tabular}{ccccc}
\hline Sub-Dimension & $N$ & $A$ & $S D$ & Level of Self-Efficacy \\
\hline Planning the speech & 843 & 3.49 & .68028 & High \\
Speech process & 843 & 3.87 & 53379 & High \\
Linguistic structure & 843 & 3.70 & .64560 & High \\
$\quad$ Audience factor & 843 & 4.10 & .63977 & High \\
Overall Speaking Self- & 843 & 3.69 & .54143 & High \\
Efficacy & & & & \\
\hline
\end{tabular}

The data shows that the university students' speaking self-efficacy beliefs were high in overall and in the sub-dimensions of the scale. The results of the t-test are presented in Table 4, regarding the statistical difference between the university students' scores based on gender.

Table 4. Difference in Self-Efficacy Beliefs Based on Gender

\begin{tabular}{cccccccc}
\hline \multirow{2}{*}{ SSES } & Gender & $\boldsymbol{N}$ & $\boldsymbol{A}$ & $\boldsymbol{S D}$ & $\boldsymbol{t}$ & $\boldsymbol{s} \boldsymbol{d}$ & $\boldsymbol{p}$ \\
\cline { 2 - 8 } & Female & 454 & 3.7242 & .53662 & 1.457 & 841 & .146 \\
& Male & 389 & 3.6698 & .54621 & 1.455 & 816.701 & .146 \\
\hline
\end{tabular}




$$
\mathrm{N}=843, \mathrm{p}>.05
$$

As is seen in Table 4, a significant difference ( $p>.05$ ) was not found in the students' scores on the SSES based on gender. The results of the Mann Whitney $U$ test are presented in Table 5, regarding the statistical difference between the university students' scores on the SSES sub-dimensions based on gender.

Table 5. Difference in the Sub-Dimensions of Self-Efficacy Beliefs Based on Gender

\begin{tabular}{|c|c|c|c|c|c|c|c|}
\hline $\begin{array}{c}\text { Sub- } \\
\text { Dimension }\end{array}$ & Gender & $N$ & $\begin{array}{l}\text { Rank } \\
\text { Mean }\end{array}$ & Rank Total & $U$ & $Z$ & $P$ \\
\hline \multirow{2}{*}{$\begin{array}{l}\text { Planning } \\
\text { the speech }\end{array}$} & Female & 454 & 406.59 & 184591.00 & 81306.000 & -1.925 & .054 \\
\hline & Male & 388 & 438.95 & 170312.00 & & & \\
\hline \multirow{2}{*}{$\begin{array}{l}\text { Speech } \\
\text { Process }\end{array}$} & Female & 454 & 457.01 & 207484.50 & 71952.500 & -4.588 & .000 \\
\hline & Male & 388 & 379.94 & 147418.50 & & & \\
\hline \multirow{2}{*}{$\begin{array}{l}\text { Linguistic } \\
\text { structure }\end{array}$} & Female & 454 & 443.75 & 201462.50 & 77974.500 & -2.876 & .004 \\
\hline & Male & 388 & 395.47 & 153440.50 & & & \\
\hline \multirow{2}{*}{$\begin{array}{l}\text { Audience } \\
\text { factor }\end{array}$} & Female & 454 & 464.36 & 210818.50 & 68618.500 & -5.558 & .000 \\
\hline & Male & 388 & 371.35 & 144084.50 & & & \\
\hline
\end{tabular}

As is seen in Table 5, no significant difference was observed in the sub-dimension "planning the speech" based on gender. However, considering the mean scores, the male students can be said to have higher self-efficacy beliefs then their female peers (438.95>406.59). On the other hand, there were significant differences in the sub-dimensions "the speech process", "linguistic structure" and "audience factor". With respect to the mean scores, the female students can be said to have more positive self-efficacy beliefs than their male peers in these sub-dimensions.

The descriptive statistics of the ANOVA test performed to see whether the students' self-efficacy perceptions differed based on their faculties are presented in Table 6.

Table 6. Descriptive Statistics of the SSES Scores Based on Faculties

\begin{tabular}{cccc}
\hline Faculty & $\boldsymbol{N}$ & $\boldsymbol{A}$ & $\boldsymbol{S D}$ \\
\hline Education & 92 & 3.80 & .466 \\
Fine Arts & 88 & 3.63 & .572 \\
Letters & 88 & 3.89 & .573 \\
Science & 90 & 3.63 & .518 \\
Maritime & 87 & 3.62 & .484 \\
Engineering & 70 & 3.84 & .484 \\
$\quad$ Law & 88 & 3.70 & .504 \\
Economics and & 149 & 3.68 & .567 \\
Business & & & \\
Administration & & & .571 \\
Theology & 91 & 3.51 & \\
\hline
\end{tabular}

The results of the analysis show that the university students' self-efficacy beliefs differed based on the faculty in which they studied, $F(8,834)=4.538, P<.05$. The results of the Tukey's test performed to reveal between which groups the difference existed indicated that the students studying at the faculty of letters $(\bar{X}=3.89)$ had more positive self-efficacy beliefs than those studying at other faculties. 
Demirel, M., V., Türkel, A. \& Aydın, I., S., (2020). Speaking Self-Efficacy Beliefs of Turkish University Students. Cypriot Journal of Educational Science. 15(3), 399-411. DOI: 10.18844/cjes.v\%vi\%i.4905

Table 7. The ANOVA Results of the SSES Scores Based on Faculties

\begin{tabular}{|c|c|c|c|c|c|c|}
\hline & SS & $S D$ & MS & $\boldsymbol{F}$ & $p$ & \\
\hline $\begin{array}{l}\text { Between } \\
\text { Groups }\end{array}$ & 10.295 & 8 & 1.287 & 4.538 & .000 & $\begin{array}{c}\text { Education- } \\
\text { Theology; Fine }\end{array}$ \\
\hline $\begin{array}{l}\text { Within } \\
\text { Groups }\end{array}$ & 236.533 & 834 & .284 & & & $\begin{array}{c}\text { Arts-Letters; } \\
\text { Letters-Science- }\end{array}$ \\
\hline Total & 246.828 & 842 & & & & $\begin{array}{l}\text { Maritime- } \\
\text { Theology; } \\
\text { Engineering- } \\
\text { Theology }\end{array}$ \\
\hline
\end{tabular}

The results of the Kruskal Wallis test are presented in Table 8, regarding the statistical difference between the university students' scores on the SSES sub-dimensions based on faculties.

Table 8. Difference in the Sub-Dimensions of Self-Efficacy Beliefs Based on Faculties

\begin{tabular}{cccccc}
\hline $\begin{array}{c}\text { Sub- } \\
\text { Dimension }\end{array}$ & $\boldsymbol{N}$ & $\boldsymbol{A}$ & $\boldsymbol{S D}$ & $\boldsymbol{X}^{\mathbf{2}}$ & $\boldsymbol{p}$ \\
\hline $\begin{array}{c}\text { Planning } \\
\text { the speech } \\
\text { Speech } \\
\text { process }\end{array}$ & 843 & 3.4902 & .68028 & 25.370 & .001 \\
$\begin{array}{c}\text { Linguistic } \\
\text { structure }\end{array}$ & 843 & 3.8787 & .53379 & 33.7 & .000 \\
$\begin{array}{c}\text { Audience } \\
\text { factor }\end{array}$ & 843 & 4.1006 & .63977 & 22.889 & .000 \\
\hline
\end{tabular}

As is seen in Table 8, there was a statistically significant difference between the students' scores in the SSES sub-dimensions based on their faculties $(p<.05)$. It can thus be said that the university students' speaking self-efficacy beliefs differed with respect to the sub-dimensions of the scale. The Mann Whitney $U$ test was employed to determine between which faculties this difference emerged. Consequently, in the sub-dimension "planning the speech", there was a difference between the students studying at the faculties of education, letters and engineering and those studying at the faculties of maritime and theology. When the mean scores were examined, it was observed that the students studying at the faculties of education, letters and engineering had higher speaking self-efficacy beliefs in the subdimension "planning the speech". In the same sub-dimension, the students studying at the faculties of letters and engineering positively differentiated from those studying at the faculties of fine arts, science, law, and economics and business administration.

As for the sub-dimension, "the speech process", there was a difference between the faculties of education, letters, engineering and economics and business administration, and the faculties of maritime and theology. The students of the faculties in the former group were observed to have more positive speaking self-efficacy beliefs in the sub-dimension, "the speech process", than those of the faculties in the latter group. Likewise, the students studying at the faculties of letters and economics and business administration had higher self-efficacy beliefs than those studying at the faculty of fine arts. In addition, in the same sub-dimension, the self-efficacy beliefs of the students studying at the faculty of letters were more positive than those studying at the faculties of science and law.

Regarding the sub-dimension, "linguistic structure", there was a difference between the faculties of education, letters, engineering, law and economics and business administration, and the faculty theology. Accordingly, in this sub-dimension, the self-efficacy beliefs of the theology students were lower than others. In the same sub-dimension, there was also a difference between the students studying at the 
faculties of education and letters, and those studying at the faculties of fine arts, science and maritime. The students in the former group had higher self-efficacy beliefs in the sub-dimension, "linguistic structure". Moreover, the students studying at the faculty of letters had more positive self-efficacy beliefs in this sub-dimension than those of the students in law and economics and business administration.

Lastly, in the sub-dimension "audience factor", there was a difference between the faculties of education, letters, engineering and economics and business administration, and the faculties of maritime and theology. The maritime and theology students' speaking self-efficacy beliefs were lower in the audience factor than others. Furthermore, the fine arts students had higher speaking self-efficacy beliefs in this sub-dimension than the theology students. Besides, the students studying economics and business administration also had higher speaking self-efficacy beliefs in the audience factor than the science students.

The results of the analysis on whether the students' self-efficacy beliefs differed based on the number of prepared speeches they gave before are presented in Table 9.

Table 9. Descriptive Statistics of the SSES Scores Based on the Number of Prepared Speeches Given

\begin{tabular}{cccc}
\hline $\begin{array}{c}\text { Number of Prepared } \\
\text { Speeches Given }\end{array}$ & $\boldsymbol{N}$ & $\boldsymbol{A}$ & $\boldsymbol{S D}$ \\
\hline None & 40 & 3.20 & .647 \\
$\mathbf{1 - 3}$ & 450 & 3.62 & .515 \\
$\mathbf{4 - 6}$ & 153 & 3.76 & .493 \\
7 or more & 200 & 3.92 & .506 \\
\hline
\end{tabular}

The results of the analysis show that the university students' self-efficacy beliefs differed based on the number of speeches they gave before, $F(3,839)=28.649, P<.05$. The results of the Tukey test performed to see between which groups this difference existed, the students who gave seven or more prepared speeches before $(\bar{X}=3.92)$ had more positive self-efficacy beliefs. As the number of speeches given increased, self-efficacy beliefs were observed to be more positive.

Table 10. The ANOVA Results of the SSES Scores Based on the Number of Prepared Speeches Given

\begin{tabular}{ccccccc}
\hline & SS & SD & $\boldsymbol{M S}$ & $\boldsymbol{F}$ & $\boldsymbol{p}$ & \\
\hline $\begin{array}{c}\text { Between } \\
\text { Groups }\end{array}$ & 22.936 & 3 & 7.645 & 28.649 & .000 & 7 or more - \\
$\begin{array}{c}\text { Within } \\
\text { Groups }\end{array}$ & 223.892 & 839 & .267 & & & 4-6-1-3- \\
Total & 246.828 & 842 & & & & None \\
\hline
\end{tabular}

The results of the Kruskal Wallis test are presented in Table 11, regarding the statistical difference between the university students' scores on the SSES sub-dimensions based on the number of prepared speeches they gave before.

As is seen in Table 11, there was a statistically significant difference between the students' scores in the SSES sub-dimensions based on the number of prepared speeches they gave before $(p<.05)$. The Mann Whitney $U$ test was employed to determine between which quantities the difference existed. In all subdimensions, there were significant differences between the students who never gave a speech and those who gave 1-3, 4-6 and 7 or more speeches, between the students who gave 1-3 speeches and 4-6 and 7 or more speeches, and between those who gave 4-6 speeches and 7 or more speeches before. Based on this finding, it can be stated that the university students' speaking self-efficacy skills were directly proportionate to the number of prepared speeches they gave in the past. 
Table 11. Difference in the Sub-Dimensions of Self-Efficacy Beliefs Based on the Number of Prepared Speeches given

\begin{tabular}{|c|c|c|c|c|c|c|}
\hline $\begin{array}{c}\text { Sub- } \\
\text { Dimension }\end{array}$ & $\begin{array}{c}\text { Number of } \\
\text { Prepared } \\
\text { Speeches }\end{array}$ & $N$ & $\begin{array}{l}\text { Rank } \\
\text { Mean }\end{array}$ & $S D$ & $X^{2}$ & $p$ \\
\hline Planning & None & 40 & 244.06 & .68028 & 74.573 & .000 \\
\hline \multirow[t]{3}{*}{ the speech } & $1-3$ & 450 & 382.53 & & & \\
\hline & $4-6$ & 153 & 441.62 & & & \\
\hline & 7 or more & 200 & 531.39 & & & \\
\hline Speech & None & 40 & 269.20 & .53379 & 39.080 & .000 \\
\hline \multirow[t]{3}{*}{ process } & $1-3$ & 450 & 395.12 & & & \\
\hline & $4-6$ & 153 & 453.01 & & & \\
\hline & 7 or more & 200 & 489.31 & & & \\
\hline Linguistic & None & 40 & 284.76 & .64560 & 37.328 & .000 \\
\hline \multirow[t]{3}{*}{ structure } & $1-3$ & 450 & 394.68 & & & \\
\hline & $4-6$ & 153 & 443.74 & & & \\
\hline & 7 or more & 200 & 494.29 & & & \\
\hline \multirow{4}{*}{$\begin{array}{l}\text { Audience } \\
\text { factor }\end{array}$} & None & 40 & 316.23 & .63977 & 14.002 & .003 \\
\hline & $1-3$ & 450 & 409.50 & & & \\
\hline & $4-6$ & 153 & 460.31 & & & \\
\hline & 7 or more & 200 & 441.97 & & & \\
\hline
\end{tabular}

The results of the analysis on whether the students' self-efficacy beliefs differed based on the average number of books they read annually are presented in Table 12.

Table 12. Descriptive Statistics of the SSES Scores Based on the Average Number of Books Read Annually

\begin{tabular}{cccc}
\hline $\begin{array}{c}\text { Average number of } \\
\text { books }\end{array}$ & $\mathbf{N}$ & $\mathbf{A}$ & SD \\
\hline No books & 26 & 3.56 & .503 \\
$\mathbf{1 - 3}$ & 104 & 3.54 & .530 \\
$\mathbf{4 - 6}$ & 251 & 3.61 & .542 \\
$\mathbf{7}$ or more & 462 & 3.78 & .530 \\
\hline
\end{tabular}

According to the results, the university students' self-efficacy beliefs differed based on the average number of books they read annually, $F(3,839)=9,356, p<, 05$. The results of the Tukey's posthoc test revealed that the students who read seven or more books a year had more positive self-efficacy beliefs than those who did not read any books or read 1-3 and 4-6 books a year.

Table 13. The ANOVA Results of the SSES Scores Based on the Average Number of Books Read Annually

\begin{tabular}{ccccccc}
\hline & SS & SD & MS & $\boldsymbol{F}$ & $\boldsymbol{p}$ & \\
\hline $\begin{array}{c}\text { Between } \\
\text { Groups }\end{array}$ & 7.990 & 3 & 2.663 & 9.356 & .000 & 7 or more - \\
$\begin{array}{l}\text { Within } \\
\text { Groups }\end{array}$ & 238.838 & 839 & .285 & & & $1-3-4-6$ \\
Total & 246.828 & 842 & & & & \\
\hline
\end{tabular}


Demirel, M., V., Türkel, A. \& Aydın, I., S., (2020). Speaking Self-Efficacy Beliefs of Turkish University Students. Cypriot Journal of Educational Science. 15(3), 399-411. DOI: 10.18844/cjes.v\%vi\%i.4905

The results of the Kruskal Wallis test are presented in Table 14, regarding the statistical difference between the university students' scores on the SSES sub-dimensions based on the average number of books they read annually.

Table 14. Difference in the Sub-Dimensions of Self-Efficacy Beliefs Based on the Average Number of Books Read Annually

\begin{tabular}{|c|c|c|c|c|c|c|}
\hline $\begin{array}{c}\text { Sub- } \\
\text { Dimension }\end{array}$ & $\begin{array}{c}\text { Intervals } \\
\text { of } \\
\text { numbers }\end{array}$ & $N$ & $\begin{array}{l}\text { Rank } \\
\text { Mean }\end{array}$ & $S D$ & $x^{2}$ & $p$ \\
\hline \multirow{4}{*}{$\begin{array}{l}\text { Planning } \\
\text { the speech }\end{array}$} & No books & 26 & 358.12 & .68028 & 21.812 & .000 \\
\hline & $1-3$ & 104 & 362.13 & & & \\
\hline & $4-6$ & 251 & 389.75 & & & \\
\hline & 7 or more & 432 & 456.59 & & & \\
\hline Speech & No books & 26 & 360.15 & .53379 & 21.027 & .000 \\
\hline \multirow[t]{3}{*}{ process } & $1-3$ & 104 & 351.40 & & & \\
\hline & $4-6$ & 251 & 398.12 & & & \\
\hline & 7 or more & 432 & 354.34 & & & \\
\hline \multirow{4}{*}{$\begin{array}{l}\text { Linguistic } \\
\text { structure }\end{array}$} & No books & 26 & 392.50 & .64560 & 27.903 & .000 \\
\hline & $1-3$ & 104 & 346.50 & & & \\
\hline & $4-6$ & 251 & 385.10 & & & \\
\hline & 7 or more & 432 & 460.71 & & & \\
\hline \multirow{4}{*}{$\begin{array}{l}\text { Audience } \\
\text { factor }\end{array}$} & No books & 26 & 396.98 & 63977 & 5.883 & .117 \\
\hline & $1-3$ & 104 & 386.70 & & & \\
\hline & $4-6$ & 251 & 406.91 & & & \\
\hline & 7 or more & 432 & 439.55 & & & \\
\hline
\end{tabular}

The results revealed significant differences between the students' self-efficacy scores based on the average number of books they read annually $(p<.05)$ in all sub-dimensions, except the audience factor. The Mann Whitney $U$ test was utilised to see between which groups this difference emerged. Accordingly, the students who reported not to read any books and those who read seven or more books significantly differed only in the sub-dimension of planning the speech. The students who read seven or more books had higher speaking self-efficacy in this sub-dimension. There were also differences between the students who read 1-3 and 4-6 books and those who read seven or more books in the sub-dimensions, "planning the speech", "the speech process" and "linguistic structure". The students who read seven or more books had higher speaking self-efficacy beliefs than the others in all sub-dimensions.

\section{Discussion and Conclusion}

This study was conducted with the data collected from final-year Turkish university students studying in different faculties. According to the findings revealed in the study, the students' speaking self-efficacy levels were considerably high based on their scores on the scale. In the literature, the studies on mostly teacher candidates support this finding (Günay 2003; Pehlivan Baykara 2005; Çiftçi \& Taşkaya 2010; Maden 2010; Çetinkaya 2011; Er \& Demir 2013; Aykaç \& Çetinkaya 2013; Katrancı, 2014; Aydın Başoğlu 2014; Çakır \& Aydın 2015; İşcan, Karagöz \& Almalı 2017; Paradewari 2017). There was no significant difference between the students' self-efficacy beliefs based on gender, which is consistent with the findings of Günay (2003), Pehlivan Baykara (2005), Çiftçi and Taşkaya (2010), Akın (2016) and Özden (2018). However, Çakır and Aydın's study (2015) in which they administered the same scale to teacher candidates and found that the female participants had higher self-efficacy beliefs than the male participants.

In the present study, the university students were observed to differ in their speaking self-efficacy beliefs based on their faculties. The self-efficacy beliefs of the students studying at the faculty of letters 
Demirel, M., V., Türkel, A. \& Aydın, I., S., (2020). Speaking Self-Efficacy Beliefs of Turkish University Students. Cypriot Journal of Educational Science. 15(3), 399-411. DOI: 10.18844/cjes.v\%vi\%i.4905

were more positive than those studying at other faculties. On the other hand, the students of the theology faculty had the lowest speaking self-efficacy beliefs. The analysis regarding the variable of experience in prepared speeches revealed a significant difference in the students' speaking self-efficacy beliefs. The students who gave seven or more prepared speeches before had higher speaking self-efficacy beliefs, and as the number of prepared speeches given increase, the speaking self-efficacy beliefs also get higher. It can thus be argued that students' speaking self-efficacy can be improved by giving them opportunities to make prepared speeches. According to Oğuz (2009), factors such as not having prior practice and inexperience are the sources of inefficacy that teacher candidates have in verbal and written communication. Likewise, Akın (2016) reported that students who had received a speaking course had higher speaking self-efficacy beliefs. As Altunkaya (2017) indicates, activity-oriented verbal communication classes are fruitful as sources of all self-efficacy beliefs. Studies including Liu (2013) and Paradewari (2017) support the argument that the experience of speaking in front of a crown increases self-efficacy. The results of these studies highlight the importance of carrying out speaking activities in learning processes.

In the present study, the university students' speaking self-efficacy beliefs were found to differ based on their annual amount of reading. The students who read seven or more books a year had higher speaking self-efficacy beliefs than the others. As their amount of reading went up, the speaking self-efficacy beliefs also showed an increase. This is consistent with the findings reported in Oğuz (2009), Sallabaş (2012), Demir (2017), and Tekşen and Çinpolat (2018).

Regarding the sub-dimensions of the SSES, there were significant differences in the students' selfefficacy beliefs based on gender, expect the sub-dimension "planning the speech". In the sub-dimensions "the speech process", "linguistic structure" and "audience factor", the female students' speaking selfefficacy beliefs were more positive than those of their male peers. Kuru (2018) who employed the same scale also reported significant differences in the sub-dimensions "the speech process" and "audience factor"; however, the male students' speaking self-efficacy beliefs were found to be higher in these subdimensions. The fact that the difference based on gender in two different studies employing the same scale turnout out to be in favour of both genders and that there was no difference in the whole scale may show that gender is not an influential variable on speaking self-efficacy beliefs.

Significant differences were also found in the sub-dimensions of the SSES based on faculties. In the speech process, the speaking self-efficacy beliefs of the students studying at the faculties of education, letters and engineering were more positive than those studying in the faculties of maritime, theology, science, economics and business administration and fine arts. In this sub-dimension, the speaking selfefficacy beliefs of the students studying at the faculties of education, letters, engineering and economics and business administration were higher than those studying in other faculties. In the sub-dimension "linguistic structure", the speaking self-efficacy beliefs of the students studying in the faculties of education and letters were higher than the others. As for the sub-dimension "audience factor", the speaking self-efficacy beliefs of the students studying at the faculties of education, letters, engineering and economics and business administration were also higher than those studying in other faculties. In overall, the students studying in the faculties of education and letters had higher speaking self-efficacy beliefs in the sub-dimensions of the SSES.

A significant difference was observed with regard to the students' experience in prepared speech. In all sub-dimensions, as the number of previous speeches made increased, the students' speaking self-efficacy beliefs also increased. This result overlaps with the results revealed for the whole scale. There were significant differences based on the annual number of books read in all sub-dimensions except the audience factor. The students who read seven or more books had higher speaking self-efficacy beliefs in the sub-dimensions "planning the speech" "the speech process" and "linguistic structure". The lack of a significant difference based on the amount of reading in the audience factor can be explained with the fact that the items in this sub-dimension were towards practice, and that reading is an activity towards the passive domain of the speaking experience. 
Demirel, M., V., Türkel, A. \& Aydın, I., S., (2020). Speaking Self-Efficacy Beliefs of Turkish University Students. Cypriot Journal of Educational Science. 15(3), 399-411. DOI: 10.18844/cjes.v\%vi\%i.4905

\section{Recommendations}

As a result, Turkish university students' speaking self-efficacy beliefs were found to be at a good level in the present study. Yet, it can be argued that improving the current level is possible through participation in more prepared speech activities and gaining a reading habit.

The following suggestions can be offered based on the findings of the study:

1. A replication study can be conducted in different universities and faculties.

2. Comparisons can be made by gathering data from students with different years of study in the same faculties.

3. Other variable that have the potential to predict students' speaking self-efficacy beliefs can be examined.

4. Quantitative, qualitative and mixed-method studies of different types can be carried out to get to the bottom of students' speaking self-efficacy beliefs.

5. Speaking self-efficacy beliefs should be considered as one of the dimensions that contribute to the career planning of university students, and longitudinal studies should be carried out to monitor students' development of speaking self-efficacy throughout their education.

6. Communication courses should be taught to enhance students' effective communication skills and self-efficacy beliefs as crucial elements for their professional development.

\section{REFERENCES}

Adams, K. (2004). Modelling Success: Enhancing International Postgraduate Research Students' Self-Efficacy for Research Seminar Presentations. Higher Education Research \& Development Vol. 23, No. 2, p.115-130. https://doi.org/10.1080/0729436042000206618

Akın, E. (2016). Turkçe Ogretmen Adaylarının Konuşma Oz Yeterliliklerinin Cesitli Degiskenler Acısından Incelenmesi (Siirt Universitesi Örnegi) (Turkish Teacher Candidates'speech Self Efficacy Levels In The Aspect Of Different Variables (Siirt University Example)). Route Educational Social Science Journal. Volume 3(1), p.75-90. http://www.ressjournal.com/Makaleler/758328386_6-Erhan\%20AKIN.pdf

Altunkaya, H. (2017). The Impact of Activity-Based Oral Expression Course on Speech Self-Efficacy of Students. Journal of Education and Training Studies. Vol. 6, No.1, p. 137-150. https://doi.org/10.11114/jets.v6i1.2832

Asakereh, A. \& Dehghannezhad, M. (2015) Student Satisfaction with EFL Speaking Classes: Relating Speaking SelfEfficacy and Skills Achievement. Issues in Educational Research, 25(4), p.345-363. http://www.iier.org.au/iier25/asakereh.pdf

Aydın, E. \& Başoğlu, N. (2014). Cagrı Merkezi Hizmetleri Programı Ogrencilerinin Konusma Becerileri Ozyeterlik Algıları Caycuma Meslek Yüksekokulu Ornegi (Perceptions of Self-Sufficiency for Speaking Abilities of Students of Call Center Services: Instance of Caycuma Vocational School). Elekronik Mesleki Gelisim ve Arastırmalar Dergisi (EJOIR), Cilt2, No. 3, p. 33-43. http://dergipark.org.tr/tr/pub/ejoir/issue/5378/72985

Aydın, i. S. (2013) Ogretmen Adaylarının Konusma Oz Yeterliklerine Iliskin Olcek Gelistirme Calısması (Development of a Speaking Self-Efficacy Scale for Teacher Candidates). Akdeniz Egitim Arastırmaları Dergisi, Sayı 14, p. 33-46. https://mjer.penpublishing.net/makale/333

Aykaç, M. \& Çetinkaya, G. (2013). Yaratıcı Drama Etkinliklerinin Turkce Ogretmen Adaylarının Konusma Becerilerine Etkisi (The Effect of Creative Drama Activities on Preservice Turkish Language Teachers' Speaking Skills). Turkish Studies - International Periodical For The Languages, Literature and History of Turkish or Turkic, Volume 8/9 Summer 2013, 671-682. http://www.turkishstudies.net/files/turkishstudies/1679127488_047Ayka\%C3\%A7Murtaza-vd-671-682.pdf

Bandura, A. (1982). Self-efficacy mechanism in human agency. American Psychologist, 37(2), 122147. https://doi.org/10.1037/0003-066X.37.2.122

Bandura, A. (1986). Social Foundations of Thought and Action: A Social Cognitive Theory. Englewood Cliffs, $\mathrm{NJ}:$ Prentice-Hall.

Bandura, A. (1993). Perceived Self - Efficacy in Cognitive Development and Functioning. Educational Psychologist, 28(2), p.117-148. https://www.uky.edu/ eushe2/Bandura/Bandura1993EP.pdf

Çakır, H. \& Aydın, i.S. (2015) Ogretmen Adaylarının Konusma Oz Yeterliklerine Yonelik Bir Arastırma. International Journal of Languages Education and Teaching, p. 1333-1348. 
Demirel, M., V., Türkel, A. \& Aydın, I., S., (2020). Speaking Self-Efficacy Beliefs of Turkish University Students. Cypriot Journal of Educational Science. 15(3), 399-411. DOI: 10.18844/cjes.v\%vi\%i.4905

Çetinkaya, Z. (2011). Turkçe Oğretmen Adaylarının Iletisim Becerilerine Iliskin Görüslerinin Belirlenmesi (Identifying Turkish Pre-Service Teachers' Views Related to Communication Skills). Kastamonu Eğitim Dergisi, 19 (2), 567-576. https://dergipark.org.tr/tr/pub/kefdergi/issue/49052/625770

Çiftçi, S. \& Taşkaya, S. M.(2010). Sınıf Ogretmeni Adaylarının Oz Yeterlik ve İletisim Becerileri Arasındaki Ilişki (The Relationship Between Self-Ability And Communication Skills Of The Applicants For Primary School Teaching). EJournal of New World Sciences Academy, 5 (3), p.921-928. https://www.academia.edu/12760112/SINIF_\%C3\%96\%C4\%9ERETMENi_ADAYLARININ_\%C3\%96Z_YETERLiK_V E_iLET\%C4\%B0\%C5\%9E\%C4\%B0M_BECER\%C4\%B0LER\%C4\%B0_ARASINDAK\%C4\%B0_\%C4\%B0L\%C4\%B0\%C5\%9 EK\%C4\%BON\%C4\%BON_\%C4\%BONCELENMES\%C4\%B0?auto=download

Demir, S. (2017). An Evaluation of Oral Language: The Relationship between Listening, Speaking and Self-efficacy. Universal Journal of Education Research 5(9), p.1457-1467. DOI: 10.13189/ujer.2017.050903

Dwyer, K. K. \& Fus, D. A. (1999). Communication Apprehension, Self-Efficacy, and Grades in the Basic Course: Correlations and Implications. Basic Communication Course Annual, Vol. 11 [1999], Art. 9 Available at: http://ecommons.udayton.edu/bcca/vol11/iss1/9

Dwyer, K. K., \& Fus, D. A. (2002). Perceptions of Communication Competence, Self Efficacy, and Trait Communication Apprehension: Is there an Impact on Basic Course Success? Communication Research Reports, 19, p. $29-37$. DOI: $10.1080 / 08824090209384829$

Er, O. \& Demir, Ö. (2013). Konusma Becerisinin Turkçe Ogretmenleri Tarafından Kullanılabilirligine Iliskin Turkce Ogretmeni Adaylarının Görüslerinin Incelenmesi (An Investigation of Speaking Skills of Turkish Teachers From The Viewpoint of The Preservice Turkish Teaching Teachers). Turkish Studies - International Periodical For The Languages, Literature and History of Turkish or Turkic, Volume 8/1 Winter 2013, p.1417-1436. http://www.acarindex.com/dosyalar/makale/acarindex-1423933196.pdf

Ferris, D. (1998). Students' views of Academic Aural/Oral Skills: A Comparative Needs Analysis. TESOL Quarterly, 32(2), p. 289-318. https://doi.org/10.2307/3587585

Günay, K. (2003). Sınıf Yonetiminde Ogretmenlerin Iletisim Becerilerinin Degerlendirilmesi. Yayımlanmamış Yüksel Lisans Tezi, Çukurova Üniversitesi, Adana.

İşcan, A. \& Karagöz, B. (2016). Yabancı Dil Olarak Turkce Ogretiminde Konusma Becerisi Kazandırmada Filmlerin Kullanımı (The Use of Films to Help Students Gain Speaking Abılıty in Teaching Turkish as a Foreign Language). Atatürk Üniversitesi Sosyal Bilimler Enstitüsü Dergisi, Cilt 20, Sayı 4, p. $1265 \quad$ - 1278. https://dergipark.org.tr/tr/pub/ataunisosbil/issue/26966/283397

İşcan, A. (2013) Iletisim, Konusma ve Konusmayla Ilgili Temel Kavramlar. A. Kılınç ve A. Şahin (Ed.), Konusma Egitimi (p.1-27). 2. Baskı. Ankara: Pegem Akademi.

İşcan, A., Karagöz, B., \& Almalı, M. (2017). Ogretmen Adaylarının Sozlu Anlatım Dersine ve Sozlu Anlatıma Yonelık Tutumları Uzerine Bir Çalisma (A Study on the Attitudes of Teacher Candidates towards Verbal Lecture Course and Verbal Lecture). Uluslararası Türk Eğitim Bilimleri Dergisi, Yıl 5, Sayı $8, \quad$ s. $42-63$. https://dergipark.org.tr/tr/pub/goputeb/issue/34591/382004

Katrancı, M. \& Melanlığlu, D. (2013). Ogretmen Adaylarına Yonelik Konusma Oz Yeterlik Olcegi: Gecerlik ve Güvenilirlik Çalısması (An Investigation into The Validity and Reliablity of Speaking Self-Efficacy Scale for PreService Teachers). The Jouranl of Academic Social Science Studies, Volume6 Issue 6, p. 651-665. http://dx.doi.org/10.9761/JASSS1407

Katrancı, M. (2014). Ogretmen Adaylarının Konusma Becerisine Yonelik Oz Yeterlik Algıları (Pre-service Teachers' Selfefficacy Perception of their Speaking Skills). Bartın Üniversitesi Eğitim Fakültesi Dergisi. Cilt 3, Sayı2, p. 174-195. http://oaji.net/articles/2014/691-1418210706.pdf

Kuru, O. (2018). Analysis of Classroom Teaching Candidates' Speaking Self-efficacy in Terms of Different Variables. International Journal of Education \& Literacy Studies IJELS 6(3):, p.76-83. http://dx.doi.org/10.7575/aiac.ijels.v.6n.3p.76

Liu, M. (2013). English Bar as a Venue to Boost Students' Speaking Self-Efficacy at the Tertiary Level. English Language Teaching, Vol. 6, No. 12, p. 27-37. http://dx.doi.org/10.5539/elt.v6n12p27

Maden, S. (2010). Turkce Ogretmeni Adaylarının Sozlu lletisim Becerileri Uzerine Bir Arastirma (A Study on Preservice Turkish Teachers' Verbal Communication Skills ). EKEV Akademi Dergisi Yıl:14 Sayı44, p. 145 - 154. http://acikerisim.giresun.edu.tr/xmlui/bitstream/handle/123456789/320/Sedat\%20Maden23.pdf?sequence=1 \&isAllowed=y 
Oğuz, A. (2009). Ogretmen Adaylarının Sozlu ve Yazılı Anlatim Becerilerine İliskin Oz Yeterlik Algilari (Trainee Teachers' Self-Efficacy Perceptions Regarding Their Written and Oral Expression Skills). Elektronik Sosyal Bilimler Dergisi. C.8, S.30 (p.18-42). https://dergipark.org.tr/tr/pub/esosder/issue/6144/82460

Özden, M. (2018). Turkce Egitimi Lisans Ogrencilerinin Konusma Becerisi Oz Yeterlikleri (Speech Self-Sufficiency of Undergraduate Students in Turkish Education). Uluslararası Türkçe Edebiyat Kültür Eğitim Dergisi Sayı: 7/3 2018 p. 1917-1930. https://dergipark.org.tr/tr/pub/teke/issue/39454/465285

Pajares, F. (2003). Self-Efficacy Beliefs, Motivation, and Achıvement in Writing: A Review of The Literature. Reading \& Writing Quarterly, 19: 1397158 (Taylor \& Francis). DOI: 10.1080/10573560390143085

Pajares, F., Johnson, M. J. \& Usher, E. L. (2007). Sources of Writing Self-Efficacy Beliefs of Elementary, Middle, and High School Students. Research in the Teaching of English, Vol. 42, No. 1 (Aug., 2007), p. 104-120. https://www.jstor.org/stable/40171749?seq=1\#metadata_info_tab_contents

Paradewari, D. S. (2017). Investigating Students' Self-Efficacy of Public Speaking. International Journal of Education and Research Vol. 5 No. p.97-108. https://www.ijern.com/journal/2017/October-2017/09.pdf

Pehlivan Baykara, K. (2005). Ogretmen Adaylarinin Iletisim Becerisi Algilari Uzerine Bir Çalisma (A Study on Perception of Communication Skills of Preservice Teachers). Ilköğretim Online, 4 (2), p. 17-23. http://ilkogretimonline.org.tr/index.php/io/article/viewFile/2014/1850

Şahan, M. (2012). 10-12 Yas Arası Ilkogretim Ogrencilerinin Konusma Yeterlilikleri ve Konusma Becerisinin Gelistirilmesine Yonelik Atolye Ornekleri. Uluslararası Türkçenin Eğitimi - Öğretimi Kurultayı, 05-06 Temmuz 2012, Mersin.

Sallabaş, M.E. (2012). Turkceyi Yabancı Dil Olarak Ogrenenlerin Konusma Oz Yeterliliklerinin Degerlendirilmesi (Assessment of Self-Efficacies of Learners of Turkish as a Foreign Language). Türkiye Sosyal Araştırmalar Dergisi (TSA). Yıl: 16, S:2, p.269-290. https://dergipark.org.tr/tr/pub/tsadergisi/issue/21489/230355

Schunk, D. H. (1995). Self-efficacy and Education and Instruction. In J. E. Maddux (Ed.), Selfefficacy, Adaptation, and Adjustment: Theory, Research, and Application (p. 2817303). New York: Plenum Press. https://libres.uncg.edu/ir/uncg/f/D_Schunk_Self_1995.pdf

Schunk, D. H. (2003). Self-Efficacy For Reading and Writing: Influence of Modeling, Goal Setting, and Self-Evaluation. Reading \&Writing Quarterly, 19:2, p.159-172, DOI: 10.1080/10573560308219

Ünalan, Ş. (2007). Sozlu Anlatim. Ankara: Nobel Publishing.

Uzuner Yurt, S. \& Aktaş E. (2016). The Effects of Peer Tutoring in University Students' Success, Speaking Skills and Speech Self-Efficacy in The Effective and Good Speech Course. Academic Journals - Educational Research and Reviews, Vol.11(11), p. 1035-1042. https://doi.org/10.5897/ERR2016.2718

Warren, J. L. (2011). "The Relatıonshıp Between Servıce Learnıng and Publıc Speakıng Self-Effıcacy: Toward Engagıng Today's Undergraduates".Theses and Dissertations--Communication. 